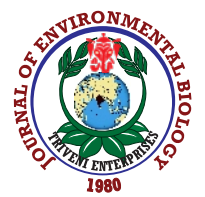

\title{
Biomolecular characterization and efficacy evaluation of pathogen Erwinia tracheiphila against plant oils
}

\author{
S. Pattanayak', G. Biswal' ${ }^{1}$ and S. Das ${ }^{1 *}$ \\ ${ }^{1}$ Department of Plant Pathology, MS Swaminathan School of Agriculture, Centurion University of Technology and Management, Gajapati-761 211, India \\ ${ }^{2}$ Department of Plant Pathology, College of Agriculture, Orissa University of Agriculture and Technology, Bhubaneswar-751 003, India
}

*Corresponding Author Email : siddhartha.das10@gmail.com

\section{Abstract}

Aim: To investigate patho-dyanamics of Erwinia tracheiphila on Cucurbita pepo with biochemical, molecular characterization and eco-friendly managementapproaches.

Methodology: Variability study of Erwinia tracheiphila was done by collecting the isolates from different places in Odisha. Disease severity was calculated and analyzed from 2016-18 to predict trend of emergence and disease progress. Molecular detection of pathogen was done through $16 S$ rRNA sequencing. Biochemical characterization and identification of pathogenic nature of Erwinia tracheiphila was performed through OrthoNitrophenyl $\beta$-Galactoside, Esculin hydrolysis, Citrate and Malonate utilization in the presence of different carbohydrate molecules. Efficacy of eight different plant oils were tested by in-vitro inhibition zone (IVIZ) assay against Erwinia tracheiphila as eco-friendly management approaches.

Results: Analysis of disease severity data from 2016-18 ranged between $29 \%$ to $33 \%$. Molecular detection of causal pathogen was further confirmed by 16 S rRNA region sequencing with $99 \%$ identity of NCBIGenBank published Erwinia tracheiphila (MK356446 and MK356441) database and phylogenetic analysis. The results of IVIZT revealed that the clove oil treatment showed maximum inhibitory effect on the growth of Erwinia tracheiphila followed by mustard oil and neem oil. Sesamum oil showed the lowest efficacy against Erwinia tracheiphila. Optimum

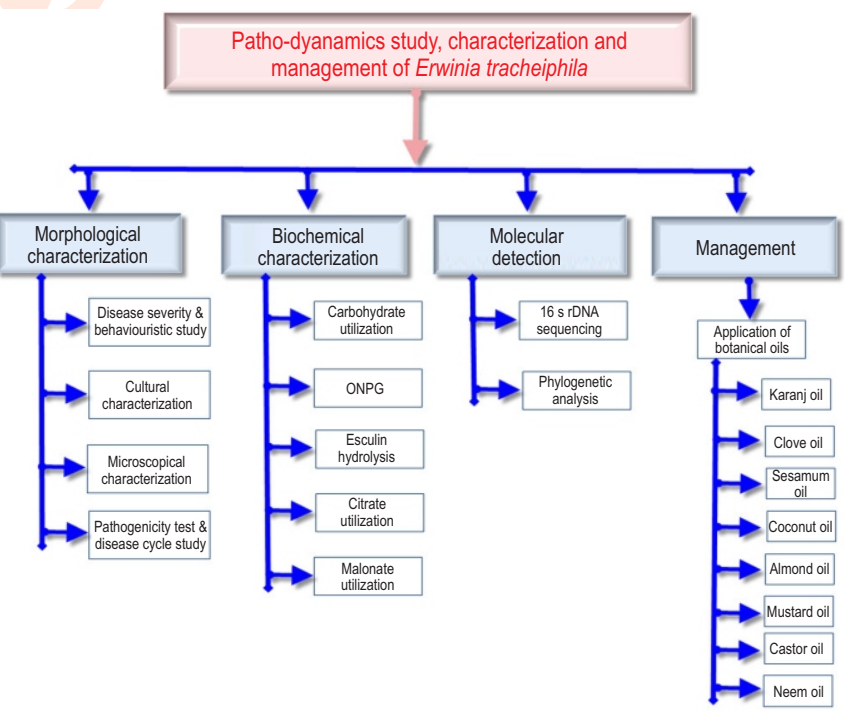
temperature range between $25-28^{\circ} \mathrm{C}, 80-85 \%$ relative humidity and 150 $180 \mathrm{~mm}$ average rainfall triggered the disease progress and turned to be a severe one under experimental agro-climatic situation.

Interpretation: Biochemical characterization and molecular detection of causal isolate confirmed the pathogen as Erwinia tracheiphila, causing wilt disease of Cucurbita pepo. This study also revealed the potential efficacy of clove oil and mustard oil against Erwinia tracheiphila as compared to other selected plant oils.

Key words: Erwinia tracheiphila, Molecular detection, Patho-dyanamics, Plant oils

How to cite : Pattanayak, S., G. Biswal and S. Das: Biomolecular characterization and efficacy evaluation of pathogen Erwinia tracheiphila against plant oils. J. Environ. Biol., 42, 988-994 (2021). 


\section{Introduction}

Pumpkin (Cucurbita pepo) is considered to be one of the highly nutritious cucurbits belongs to squash ancestors. Pumpkins are diversified cosmopolitically with multipurpose approaches in different field. India is the second highest producer in the world after China (Dhiman et al., 2009). The highest pumpkin growing state in India is Orissa (459.83 mt), followed by Uttar Pradesh (360.16 mt), Madhya Pradesh (273.30 mt) (NHB, 2015-16). Cucurbits belong to large, diverse crop group that are susceptible to over 200 diseases (Zitter et al., 1996). Bacterial wilt of cucurbit is considered to be a major devastating disease in the emerging scenario. Among all the cucurbits, the most susceptible one towards bacterial wilt is cucumber which is followed by muskmelon and pumkin (Sarkar and Choudhuri, 2016). It can cause severe yield loss in cucumber (Cucumis sativus) and muskmelon (Cucumis melo) fields in the Eastern and Midwestern U.S. (Brust et al., 1999; Mackiewicz et al., 1998, Shapiro et al., 2015) and Southeastern Canada (Toussaint et al., 2013). In India, the increased level of disease severity makes the pathogen a major one for cucurbits. Economic losses can reach up to $75 \%$ in bacterial wilt (Zehnder et al., 1997).

Erwinia tracheiphila is a Gram negative rod shaped, and xylem-limited facultative anaerobic bacteria containing peritrichous flagella. The pathogen is transmitted by frass of striped (Acalymma vittatum) and spotted (Diabrotica undecimpunctata) cucumber beetles and overwinters in the gut (Rand et al., 1916; Smith, 1911; Mitchell et al., 2009; Sasu et al., 2010). Infection mainly takes place in the presence water film which facilitates the pathogen to reach the wound and further to xylem vessels. The bacteria starts multiplying in the xylem vessel producing extracellular polysaccharides or slime which obstruct the xylem and exhibits symptoms. Initial symptoms show as wilting of leaves leading to collapse of vines. Sticky and gummy ooze can be found if the infected stems are cut transversally. Affected leaves become flassid and the insect feeding symptom can easily be distinguished as a darker green area surrounding the wound leading to dull green color of the entire plant. Inoculum dose, age related resistance, soil water availability, host and environment factors play a crucial role in symptom variation and disease progression (Liu et al., 2013).

The complex nature of infection, transmission, and survival of the pathogen under different climatic condition makes it difficult to manage the disease under field condition. Many plant oils are known to have antimicrobial effect due to the presence of potential volatile compounds. Essential oils are recognized for its non-toxic residual effect, high target specificity and eco-friendly nature which can be applied for the management of Erwinia tracheiphila. The research objective was designed to characterize and confirm the pathogen through biomolecular assay along with the efficacy test of selected plant oils in-vitro.

\section{Materials and Methods}

Isolation of the pathogen: Different isolates of pumpkin plants showing wilting symptoms were collected from five different places viz. Lingipur, Baramunda, Uttara, Polasara and Berhampur. The isolates were named as $L g I-V$, Ba I-V, Ua I-V, $\mathrm{Pa} \mathrm{I}-\mathrm{V}$ and $\mathrm{Bh} \mathrm{I}-\mathrm{V}$. Freshly collected wilted pumpkin plants were surface sterilized in $1 \%$ sodium hypochlorite solution followed by washing in distilled water to remove excess chemical. The bacterial ooze was collected and used for the isolation of bacterium. Isolation of bacterium was done on Nutrient Agar medium and then incubated in BOD incubator for $24-48$ hrs maintained at $30^{\circ} \pm 2^{\circ} \mathrm{C}$. Pure culture of bacteria was maintained by isolating the bacterial colony from well grown Nutrient Agar plates, stored at $4^{\circ} \mathrm{C}$ for future use.

Phenotypical observation and pathogenicity test of infected host: Samples were selected based on wilting severity with 5 point index scale (Inglis et al., 1988), Scale 0-no wilting, Scale 1initiation of wilt symptoms (1-10\%), Scale 2-wilting ,yellowing, browning advancement up to (11-25\%), Scale 3-plants wilted, yellow brown discoloration more pronounced, start dying of entire plant (26-50\%), Scale 4- Maximum leaf defoliation and drooping of SAM (Shoot apical meristematic region) $(<50 \%)$, Scale 5completely drying and dying (defoliation and whole plant wilting). Estimation of natural infection was calculated by percent disease index (PDI) [PDI = \{(Sum of all disease rating) $/$ (Total no of rating $\times$ maximum disease grade $)\} \times 100]$.

For pathogenicity test, bacterial suspension was prepared and the concentration of the suspension was

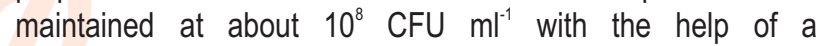
spectrophotometer using $450 \mathrm{~nm}$ filters. A small quantity of bacterial suspension was then injected at the collar portion while a set of untreated plants served as control. The incidence of bacterial wilt was confirmed by conducting ooze test in sterile water in culture tubes after five days of inoculation.

Biochemical characterization of bacterial isolate: Different biochemical tests like Esculin hydrolysis, Citrate utilization, Malonate utilization and Ortho-Nitrophenyl- $\beta$-Galactoside tests were performed by different biochemical kits from HiMedia. Biochemical tests were recorded by observing the color change in the Biochemical kit. The test for utilization of different carbohydrate tests was performed to characterize bacterial isolate. Thirty-one carbohydrates were tested further for oxidation and fermentation reaction by Erwinia tracheiphila.

DNA purification and molecular confirmation: Purified single colony of Erwinia tracheiphila was grown in nutrient broth (HiMedia) over night at $28^{\circ} \mathrm{C}$ with constant shaking. Broth cultures were centrifuged at $9000 \mathrm{rpm}$ for $15 \mathrm{~min}$ and bacterial pellets were collected in $2 \mu \mathrm{l}$ centrifuge tube by discarding supernatant. The pellets were single washed with $1 \mathrm{M} \mathrm{NaCl}$, followed by three washes with sterile water. With this mixture added proteinase K (at the rate of $50 \mu \mathrm{g} / \mathrm{ml}$ ) for the preparation of $200 \mathrm{ml}$ volume, that was the required volume for DNA extraction. With this consecutive mixture solution $10 \mathrm{mM}$ Tris-HCL (pH 7.5) and $1 \mathrm{M}$ EDTA (pH 8.0) were added. Afterwards $450 \mu$ l of proteinase $K$ was added to bacterial pellets and mixed thoroughly. The bacterial cells suspended in enzyme solution which was incubated at $56^{\circ} \mathrm{C}$ for 
15 min in hot water bath followed by deactivation of enzyme at $80^{\circ} \mathrm{C}$ for $15 \mathrm{~min}$. The mixture was then transferred instantly on ice and kept for $5 \mathrm{~min}$. Extracted DNA was purified by centrifugation at $15000 \mathrm{rpm}$ for $5 \mathrm{~min}$.

The supernatant was collected in a sterile Eppendorf tube and carried. Polymerase chain reaction was conducted with Erwinia tracheiphila specific primers forward(GGACGGCGTATTTCTTTCAA) and reverse (TCATCTTGACCGTTTTTGCTC). A total $25 \mu$ PCR reaction mixture prepared which contained $4 \mu \mathrm{LNA}, 2.5 \mu$ of $10 \mathrm{X}$ PCR buffer, $1 \mu \mathrm{l}$ each of $20 \mathrm{pm} / \mathrm{ml}$ forward and reverse primer, $1.5 \mu \mathrm{l}$ of $25 \mathrm{mM} \mathrm{Mgcl}_{2}, 0.5 \mu \mathrm{l}$ of $10 \mathrm{mM}$ dNTP's mix, $0.5 \mu \mathrm{l}$ of $1 \mathrm{U}$ Taq polymerase and $14 \mu \mathrm{l}$ of double distilled sterile water. Amplification was performed by thermocycler (MyCycler TM) by initial denaturation at $94^{\circ} \mathrm{C}$ for $2 \mathrm{~min}$; 35 cycles consisting 20 sec of denaturation at $94^{\circ} \mathrm{C}$; annealing at $68^{\circ} \mathrm{C}$; extension at $72^{\circ} \mathrm{C}$ and a final extension for $10 \mathrm{~min}$ at $72^{\circ} \mathrm{C}$. PCR products were analyzed by electrophoresis in 1.5\% agarose gel prepared in 1XTAE buffer solution.

Bio-efficacy test of selected plant oils against Erwinia tracheiphila: From twenty-five isolates collected from different regions, $\mathrm{Lg}$ V isolate was selected to conduct further experiments due to its sensitivity towards the pathogen and to get affected in lesser time. Eight different oils viz., karanj (Pongamia pinnata), clove (Syzygium aromaticum), sesamum (Sesamum indicum), virgin coconut oil (Cocos nucifera), almond (Prunus dulcis), mustard (Brassica nigra), castor (Ricinus communis) and neem (Azadirachta indica) were collected for in-vitro study against the pathogen. In vitro inhibition zone assay was performed asper agar disk diffusion method (Balouiri et al., 2016). In this method, filter paper disk of nearly $6 \mathrm{~mm}$ (diameter) size were taken in petriplates and sterilized in autoclave at $15 \mathrm{lbs}$ pressure for 20 min. After cooling and drying, the filter paper disks were dipped in test oil separately for absorption to get the required concentration of oil. Bacterial suspension was spread on the nutrient agar plate after which 4 filter paper disks were placed on each plate. Then the treated plates were kept for incubation at $30 \pm 2^{\circ} \mathrm{C}$ for $24-48$ hrs. After incubation inhibition zones were measured in $24 \mathrm{hr}$ and $48 \mathrm{hr}$.

Phylogenetic analysis: Phylogenetic tree was constructed from the analysis of $16 \mathrm{~S}$ rRNA region using neighbor joining method (among the closely related taxa from various countries derived from NCBI-Gen Bank database) by using MEGA_X_10.1.6 version (Soon-Wo et al., 1997).

Statistical analysis: The bacteria were identified by putting the results of biochemical test and carbohydrate test in ABIS (Advanced bacterial identification software) online software. The statistical data analysis was done in Completely Randomized Design (CRD) with 4 replications.

\section{Results and Discussion}

Pure cultured plates showed approximately 96 fluidial pale yellowish irregular colonies. Microscopic observation confirmed straight rod shaped Gram negative bacteria which occured singly or in pairs and sometimes in short chain, motile by peritrichous flagella. Small, slimy, shiny colonies with glistening surface type colonies were observed in nutrient agar media while slimy milky white raised shinning colonies were observed in nutrient sucrose agar as shown in Fig. 1.

Pathogenicity test further confirmed virulency of collected isolates with similar symptomatic expression. Disease severity from 2016-17 to 2017-18 were analyzed at an interval of four days $(30,60,90$ and 120$)$ which revealed that the disease incidence was higher in 2017-18 (16.12\%) as compared to $2016-17$ (13.33\%). Similarly, disease severity was higher in 2017-18 (33.36\%) than 2016-17 (29.31\%) (Table 1). Among all the biochemical tests, esculin hydrolysis, citrate utilization and ortho-nitrophenyl- $\beta$-Galactoside showed positive results, while malonate utilization test was negative. Carbohydrate test using the HiMedia kit showed the result by changing its color. Based on the result of biochemical test, the bacterial isolate showed $76.3 \%$ similarity to Erwinia tracheiphila

Table 1: Disease severity of wilt disease in Cucurbita pepo during the year 2016-17 and 2017-18

\begin{tabular}{llllllll}
\hline Year & $\begin{array}{l}\text { Days after } \\
\text { observation }\end{array}$ & $\begin{array}{l}\text { Total no } \\
\text { of plants }\end{array}$ & $\begin{array}{l}\text { Total no } \\
\text { of infected } \\
\text { plant }\end{array}$ & $\begin{array}{l}\text { No of } \\
\text { mortality }\end{array}$ & $\begin{array}{l}\text { Disease } \\
\text { incidence in } \\
\text { percentage }\end{array}$ & $\begin{array}{l}\text { Disease } \\
\text { grading }\end{array}$ & $\begin{array}{l}\text { Disease } \\
\text { severity } \\
\text { (PDI) }\end{array}$ \\
\hline \multirow{4}{*}{$2016-17$} & 30 & 90 & NIL & NIL & 0.00 & NIL & 0.00 \\
& 60 & 90 & 13 & 01 & 14.45 & $1,1,1,1,1,1,1,2,2,2,3,4,5$ & 38.46 \\
& 120 & 90 & 17 & 02 & 18.89 & $1,1,1,1,1,1,1,1,2,2,2,2,2,3,4,5,5$ & 41.17 \\
& & 90 & 17 & 02 & 20.00 & $1,1,1,1,1,1,1,1,1,1,1,2,2,3,4,5,5$ & 37.64 \\
$2017-18$ & Average (per year) & & 13.33 & - & 29.31 \\
& 30 & 90 & 06 & NIL & 6.67 & $1,1,1,1,1,2$ & 23.33 \\
& 90 & 90 & 14 & 2 & 15.59 & $1,1,1,1,1,1,1,1,1,1,2,2,5,5$ & 34.28 \\
& 120 & 90 & 18 & 3 & 21.11 & $1,1,1,1,1,1,1,1,1,1,1,2,2,3,4,5,5,5$ & 41.11 \\
& 90 & 19 & 3 & 21.11 & $1,1,1,1,1,1,1,1,1,1,1,1,1,1,2,2,5,5,5$ & 34.73 \\
\end{tabular}


Table 2: Efficacy of pure plant oils against the growth of Erwinia tracheiphila expressed as zone of inhibition $(\mathrm{mm})$

\begin{tabular}{lll}
\hline Treatments & Source of oil & Zone of inhibition \\
\hline$T_{1}$ & Karanj & 9.16 \\
$T_{2}$ & Clove & 29.55 \\
$T_{3}$ & Sesamum & 8.66 \\
$T_{4}$ & Virgin coconut & 9.99 \\
$T_{5}$ & Almond & 12.76 \\
$T_{6}$ & Mustard & 19.22 \\
$T_{7}$ & Castor & 10.74 \\
$T_{8}$ & Neem & 15.29 \\
$T_{9}$ & Control & 0.00 \\
$S E(m)$ & 0.71 & \\
$C D$ & 2.14 & \\
\hline
\end{tabular}

according to ABIS online software. A GenBank Blast Search of publicly available bacterial database showed that $1426 \mathrm{bp}$ of $16 \mathrm{~S}$ rRNA region exactly matched with $E$. tracheiphila data base (MK356446 and MK356441) with 99\% similarity and sequentially 98\% (NR_044924). The 1426 bp RNA deposited in GenBank were assigned accession number MN620381.

The results revealed that isolate MN620381 and Erwinia tracheiphila MK356441 (France), MK356446 (New Zealand) were conspecific on the same branch node, and the highest similarity (99\%) was found between them. The nearest cluster and closest taxa Pantoea ananatis GU 477763 (China), KT741012 (Russia) and DQ133548 (South Africa) from same ancestral origin with $100 \%$ bootstrap value support (Fig. 2). Antimicrobial property of selected plant oils was tested and established it as a potential arsenal for disease management (Teles et al., 2014; Chouhan et al., 2017; Radunz et al., 2019 and Raveau et al., 2020). In this study, the effect of eight different plant oils at $100 \%$ concentration were studied against bacterial growth and formation of inhibition zone around the filter paper disks were measured at 24 and $48 \mathrm{hr}$ after incubation and the average inhibition zone was calculated (Table 2).

The experimental results revealed that clove oil showed maximum inhibitory effect on the growth of Erwinia tracheiphila $(29.55 \mathrm{~mm})$ followed by mustard oil $(19.22 \mathrm{~mm})$ and neem (15.29 $\mathrm{mm})$. Sesamum oil showed the least inhibitory effect $(8.66 \mathrm{~mm})$ on bacteria. Among all the cucurbitaceous plants, watermelon has been found to be highly resistant while cucumber and muskmelon highly susceptible to bacterial wilt (Brust and Rane, 1997; Yao et al., 1996). E. tracheiphila is transmitted through mouthparts of spotted and striped cucumber beetle during feeding (Mitchell and Hanks, 2009). Erwinia tracheiphila is mainly found in the connective region of hindgut and midgut, but it can also be found in the foregut of insects. Though multiplication and spread of bacteria decreases after 3 days of insect feeding, but their existence lasted up to 35 days after pathogen acquisition. According to Mitchell and Hanks (2009), the striped cucumber beetles fed with $E$. tracheiphila smeared sandwich for $24 \mathrm{hr}$. The frass were collected in different time intervals like 24 hour, 48 hour and 72 hours to inoculate on cucumber seedlings which finally concluded the presence of the pathogen DNA from each inoculated sample. It was observed that $E$. tracheiphila moved in the xylem vessel systemically by clogging the sap flow which induced wilting symptom (Rocha et al., 2020).

From epidemiological perspective temperature range between $25-28^{\circ} \mathrm{C}$, relative humidity $80-85 \%$ and average rainfall $150-180 \mathrm{~mm}$ triggered the disease progress and turned to be a major pathogen under present agro-climatic situation. Andino and Motsenbocker (2004) revealed that several soil management practices and use of plastic mulches help to decrease the number of cucumber beetle in muskmelon, cucumber and squash. Entomopathogenic nematodes can be effective in controlling cucumber beetle larvae (Ellers-Kirk et al., 2000). Seeds applied with plant growth promoting rhizobacteria can effectively control wilt incidence in protected cultivation and field conditions (Zehnder et al., 2001) but varies in outcome depending on epidemiological conditions. Genome sequencing for $E$.
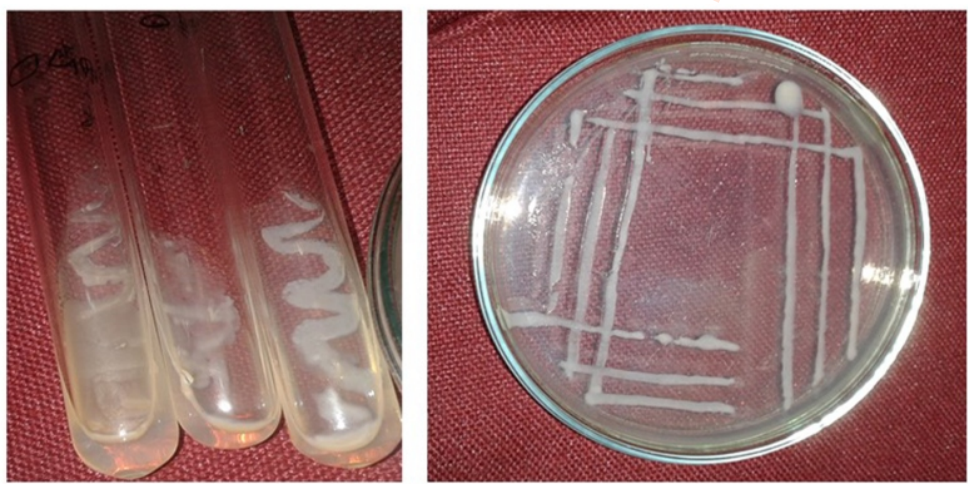

Nutrient Agar media

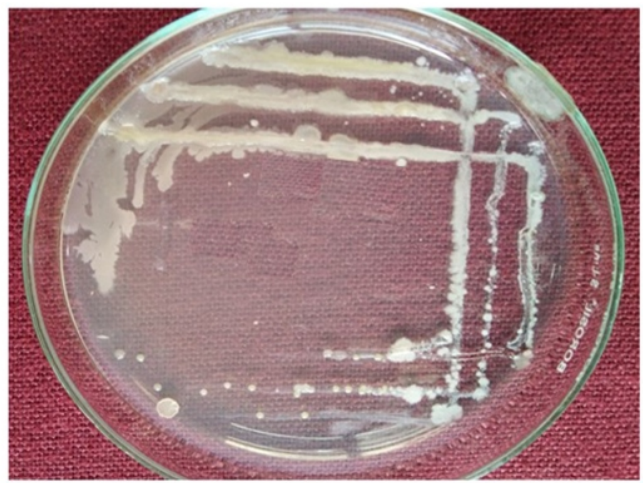

Nutrient sucrose Agar media

Fig. 1: Growth characteristic of Erwinia tracheiphila observed on Nutrient Agar and Nutrient Sucrose Agar media. Small, slimy and shiny colonies with glistening surfaces were seen in NutrientAgar media, while milky, raised slimy and shiny surfaced colonies were observed in Nutrient SucroseAgar media. 


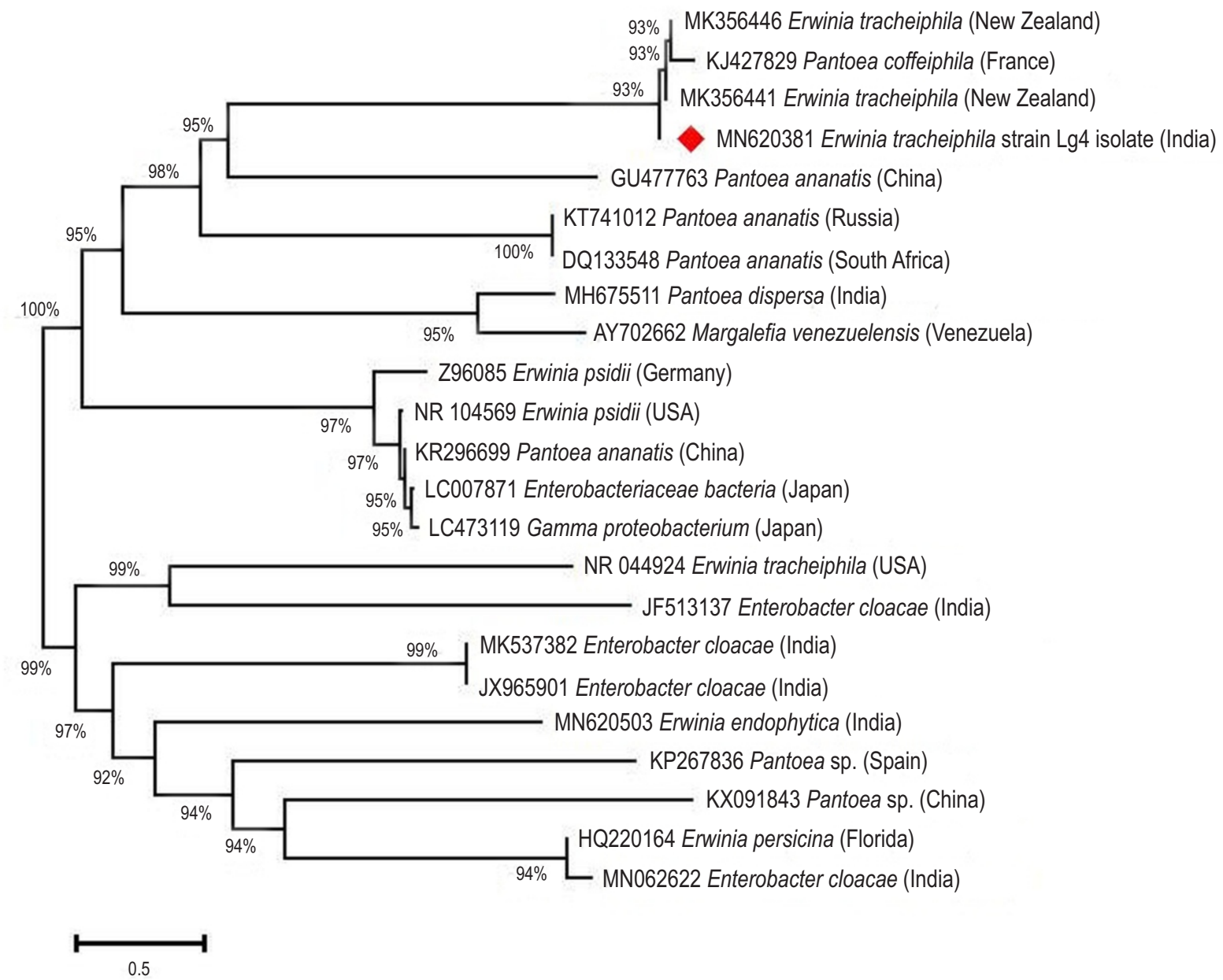

Fig. 2: Molecular phylogenetic analysis of $16 \mathrm{~S}$ rRNA region of Erwinia tracheiphila with closely related taxa obtained from Genbank by neighbor-joining tree followed maximum composite likelihood method. The nodal significance was evaluated by means of bootstrapping using 1000 replicates. Sequence obtained in the present study is marked by $(\$)$ symbol.

tracheiphila provided some hints to genes related with pathogenicity by signifying the presence of genes encoding components of a type III secretion system (Shapiro, 2012). Three genes (relA, dskA, csrA) have been found to be most important in pathogenesis of Erwinia (Luigimaria et al., 2017). The relA gene is involved in triggering ppGpp (Zhang et al., 1999) of Erwinia. The ppGpp helps in blocking or triggering active genes by interacting with RNA polymerase (RNAP). The dskA gene modifies the coupling product ppGpp-RNAP by enhancing its activity (Ancona et al., 2015). The csrA gene acts as posttranscriptional regulator (Ancona et al., 2016). Proper cultivar selection which is resistant or tolerant to insect feeding is an important key for profitable production. In 2000, Dorman and Deans revealed that several bacterial isolates were found to have lesser degree of sensitivity against different plant volatile oils such as Syzygium aromaticum, Piper nigrum, Myristica fragrance, Origanum vulgare which are known to contain wider spectrum of antibacterial activity. Similarly, Essential oils from Mustard and Clove has shown antifungal as well as antibacterial effect against some pathogens (Pradhanang et al., 2003). Essential oil formulation through emulsion and encapsulation is one of the emerging technologies with wider prospects, which glimpses biological activity and stability in economic point of view (Raveau et al., 2020).

In conclusion, the results of this study have confirmed the pathogen as Erwinia tracheiphila through biomolecular assay. Further, it also revealed that Clove oil (Syzygium aromaticum) and mustard oil (Brassica juncea) are more potential in suppressing or inhibiting the growth of Erwinia tracheiphila in-vitro. These essential oils can be used as a significant component of integrated disease management due to its antibacterial activity against wilt disease of Pumpkin. Plant oil 
based management strategy found to be most effective in near future to control Erwinia tracheiphila with an eco-friendly approach.

\section{Acknowledgment}

Authors are thankful to the Dean of Research, Vice Chancellor, OUAT for providing instrumentation and laboratory facility.

\section{Add-on Information}

Authors' contribution: S. Pattanayak: Experimental set up, preliminary data generation, manuscript writing, G. Biswal: Overall support on the research, data checking and analysis, checking of manuscript, S. Das: Framed of the proposed research, data analysis, and revision of the manuscript.

\section{Research content: The research content of manuscript is original} and has not been published elsewhere.

\section{Ethical approval: NotApplicable}

Conflict of interest: The authors declare that there is no conflict of interest.

\section{Data from other sources: NotApplicable}

Consent to publish: All authors agree to publish the paper in Journal of Environmental Biology.

\section{References}

Ancona, V., J.H. Lee, T. Chatnaparat, J. Oh, J.I. Hong and Y. Zhao: The bacterial alarmone (p)ppGpp activates the type III secretion system in Erwinia amylovora. J. Bacteriol., 1978, 1433-1443 (2015).

Ancona, V., J.H. Lee and Y. Zhao: The RNA-binding protein CsrA plays a central role in positively regulating virulence factors in Erwinia amylovora. Sci. Rep., 6, 37195 (2016).

Andino, J.R. and C.E. Motsenbocker: Colored plastic mulches influence cucumber beetle populations, vine growth and yield of watermelon. Hort. Sci., 39,1246-1249 (2004).

Balouiri, M., M. Sadiki and S.K. Ibnsouda: Methods for in vitro evaluating antimicrobial activity:Areview. J. Pharm. Anal., 6, 71-79 (2016).

Brust, G.E. and K.K. Rane: Differential occurrence of bacterial wilt in muskmelon due to preferential striped cucumber beetle feeding. Hort. Sci., 30, 1043-1045(1997).

Brust, G.E. and R.E. Foster: New economic threshold for striped cucumber beetle (Coleoptera: Chrysomelidae) in cantaloupe in the Midwest. J. Econ. Entomol., 92, 936-940 (1999).

Chouhan, S., K. Sharma and S. Guleria: Antimicrobial activity of some essential oils- Present status and future perspectives. Medicines, 4, 58 (2017).

Dhiman, A.K., Sharma, K.D. and Attri S.: Functional constituents and processing of pumpkin: A review. J. Food Sci. Technol., 46, 411$417(2009)$

Dorman, H.J.D. and S.G. Deans: Antimicrobial agents from plants: Antibacterial activity of plant volatile oils. J. App. Micro., 88, 308-
$316(2000)$

Ellers-Kirk, C.D., S.J. Fleischer, R.H. Snyder and J.P. Lynch: Potential of entomopathogenic nematodes for biological control of Acalymma vittatum (Coleoptera: Chrysomelidae) in cucumbers grown in conventional and organic soil management systems. J. Econ. Entomol., 93, 605-612(2000).

Inglis, D.A., D.J. Hagedorn and R.E. Rand: Use of dry inoculums to evaluate beans for resistance to anthracnose and angular leaf spot. Plant Dis., 72, 771-774 (1988).

Kwon, S.W., S.J. Go, H.W. Kang, J.C. Ryu and J.K. Jo: Phylogenetic analysis of Erwinia species based on $16 \mathrm{~S}$ rRNA gene sequences. Int. J. Syste. Bacteriol., 47, 1061-1067 (1997).

Liu, Q., E. Saalu Rojas, J.C. Batzer and M.L. Gleason: Impact of plant age on development of bacterial wilt on muskmelon. Phytopathology, 103, S2, 83 (2013).

Luigimaria, B., S.S. Marco, P. Ivan, O.S. Armin and B. Stefano: Conservation of Erwinia amylovora pathogenicity-Relevant genes among Erwinia genomes. Arch. Microbiol., 199, 1335-1344 (2017).

Mackiewicz, D., F.E. Gildow, M. Blua, S.J. Fleischer and F.L. Lukezic: Herbaceous weeds are not ecologically important reservoirs of Erwinia tracheiphila. Plant Disease, 82, 521-529 (1998).

Mitchell, R.F. and L.M. Hanks: Insect frass as a pathway for transmission of bacterial wilt of cucurbits. Environ. Entomol., 38, 395-403 (2009).

Pradhanang, P.M., M.T. Momol, S.M. Olson and J.B. Jones: Effects of plant essential oils on Ralstonia solanacearum population density and bacterial wilt incidence in tomato. Plant Disease, 87, 423-427 (2003).

Radunz, M., M.L.M. Trindade, T.M. Camargo, A.L. Radunz, C.D. Borges, E.A. Gandra and E. Helbig:Antimicrobial and antioxidant activity of unencapsulated and encapsulated clove (Syzygium aromaticum L.) essential oil. Food Chemi., 276, 180-186 (2019).

Rand, F.V. and E.M.A. Enlows: Transmission and control of bacterial wilt of cucurbits. J. Agricul. Res., 6, 417-434 (1916).

Raveau, R., J. Fontaine and A.L. Sahraoui: Essential oils as potential alternative biocontrol products against plant pathogens and weeds: Areview. Foods, 9, 365 (2020)

Rocha, J., L.R. Shapiro, R. Kolter: A horizontally acquired expansin gene increases virulence of the emerging plant pathogen Erwinia tracheiphila. Scientific Reports, 10, 21743 (2020).

Sarkar, S. and S. Choudhuri: Bacterial wilt and its management. Curr. Sci., 110, 1439-1445 (2016).

Sasu, M.A., K. Wall, J.A. Winsor and A.G. Stephenson: Antimicrobial nectar inhibits a florally transmitted pathogen of wild Cucurbita pepo (Cucurbitaceae). American J. Bot., 97, 1025-1030 (2010).

Shapiro, L., E.D. Scully, D. Roberts, T.J. Straub, S.M. Geib, J. Park, A. Stephenson, E.S. Rojas, Q. Liu, G. Beattie, M. Gleason, C. De Moraes, M. Mescher, S. Fleischer, R. Kolter, N. Pierce and O. Zhaxybayeva: Draft genome sequence of Erwinia tracheiphila, an economically important bacterial pathogen of cucurbits. Genome Anno., 3, e00482-15 (2015).

Shapiro, L., C.M. De Moraes, A.G. Stephenson and M.C. Mescher: Pathogens effects on vegetative and floral odours mediate vector attraction and host exposure in a complex pathosystem. Ecol. Lett., 15,1430-1438 (2012).

Smith, E.F.: Bacteria in relation to plant diseases. Carnegie Institution, Washington Publications, pp. e1-e2 (1911).

Teles Andrade, B.F., L.N. Barbosa, I. da Silva Probst, A. Fernandes Junior:Antimicrobial activity of essential oils. J. Essen. oil Res., 26, 34-40 (2014).

Toussaint, V., M. Ciotola, M. Cadieux, G. Racette, M.O. Duceppe and B. Mimee: Identification and temporal distribution of potential insect vectors of Erwinia tracheiphila, the causal agent of bacterial wilt of 
cucurbits. Phytopathology, 103, S2.147 (2013).

Yao, C., G. Zehnder, E. Bauske and J. Kloepper: Relationship between cucumber beetle (Coleoptera: Chrysomelidae) density and incidence of bacterial wilt of cucurbits. J. Econ. Entomol., 89, 510514 (1996).

Zehnder, G., J. Kloepper, C. Yao and G. Wei: Induction of systemic resistance in cucumber against cucumber beetles (Coleoptera: Chrysomelidae) by plant growth-promoting rhizobacteria. J. Econo. Entomol., 90, 391-396 (1997).
Zehnder, G.W., J.F. Murphy, E.J. Sikora and J.W. Kloepper: Application of rhizobacteria for induced resistance. Europ. J. Plant Pathol., 107, 39-50 (2001).

Zhang, Y., D.D. Bak, H. Heid and K. Geider: Molecular characterization of a protease secreted by Erwinia amylovora. J. Mol. Biol., 2895, 1239-1251 (1999).

Zitter, T.A., D.L. Hopkins and C.E. Thomas: Compendium of cucurbit diseases. American Phyto Pathological Society Press, St. Paul (1996). 